\title{
An Assessment of Financial Viability of Big Onion Seed Production in Matale District
}

\author{
H.V.C. Hewavitharane, J. Weerahewa ${ }^{1 *}$ and H.U. Warnakulasooriya \\ Progress Monitoring and Evaluation Unit \\ Department of Agriculture \\ Peradeniya, Sri Lanka
}

\begin{abstract}
Unavailability of good quality seeds of recommended big onion varieties is a major constraint for increasing the productivity of big onion cultivation in Sri Lanka. The purpose of this study was to investigate the financial feasibility of big onion production using domestically produced true seeds at farmer level. The specific objectives of the study were to compare big onion yields obtained using local and imported true seeds, compare the financial viability of big onion production using local and imported true seeds and to assess the financial viability of local true seed production in Matale district. A production function was estimated to achieve the first objective and cost benefit analysis was conducted to achieve the second and third objectives. Primary data were collected from 144 big onion farmers and 74 big onion seed farmers in Matale district. The production function estimates showed that the yield with local true seeds was 1.32 times higher than that obtained from imported true seeds. The profitability of big onion cultivation with local true seeds and imported true seeds were Rs. 27.69 and $12.95 \mathrm{per} \mathrm{kg}$, respectively, in Yala 2009. The profitability of local true seed production was Rs. 4,497 per $\mathrm{kg}$ in Maha 2008/09. These results indicate that true seed production is financially feasible at farmer level and commercial big onion production using local true seed is more financially attractive when compared to that of imported true seeds.
\end{abstract}

Key words: Big onion seeds, Cost benefit an alysis, Financial viability.

\section{INTRODUCTION}

Big onion is an important cash crop cultivated in Sri Lanka. Local production of big onion, which is approximately 81,707 MT per year, is not sufficient to meet the annual demand of big onion approximately 203,993 MT per year (DCS, 2009). Unavailability of good quality seeds of recommended varieties in adequate quantities is considered as the main constraint for increasing production of big onion in Sri Lanka (Mettananda, 2006). Furthermore, the quality of the imported big onion true seeds is not up to standard as they reach the country through illegal routes due to export restrictions in India (Edirimanna, 2003). Poor germination and bulbing, high thick neck percentage and low yield are characteristic to such seeds (Edirimanna and Rajapakshe, 2003).

With the aim of increasing the availability of good quality true seeds in Sri Lanka, the Department of Agriculture (DOA) has implemented a programme in Matale and Anuradhapura districts to enhance big onion true seed production among big onion farmers

1* To whom correspondence should be addressed : jeewikaw@pdn.ac.lk

1 Department of Agriculture Economics and Business Management, University of Peradeniya, Sri Lanka 
(DOA, 2004). The locally produced true seeds, which are labeled as "Dambullu Red" and "Galewela light red" have higher germination rates compared to imported seeds $(6 \mathrm{~kg} / \mathrm{ha}$ of local seed compared to $6.5-11 \mathrm{~kg} / \mathrm{ha}$ of imported seed (Lesly et al., 2002). However, due to the inadequacy of domestic seed and relatively high prices of domestically produced true seed, more than $70 \%$ of farmers still use imported true seeds despite their poor quality.

Although there is a general consensus about the relative advantages of using local true seeds, no proper financial analysis has been carried out so far to compare the profitability of using local true seed $v s$. imported true seed in big onion production. Therefore, objective of this study was to investigate the financial feasibility of big onion production using domestically produced true seed with farmer level. The specific objectives of the study were to: compare big onion yields obtained using local and imported true seeds, compare the financial viability of big onion production using local and imported true seed and to assess the financial viability of local true seed production in Matale district.

\section{MATERIALS AND METHODS}

\section{Production function estimation}

Primary data used in this study were gathered through farmer surveys conducted in three Agrarian Service Centre (ASC) areas in Matale district, viz. Dambulla, Kimbissa and Galewela in Yala seasons 2007 and 2009 using structured questionnaires. A stratified random sampling technique was adopted to draw commercial big onion farmers and big onion seed farmers from the above three ASC areas based on the land extent cultivated and the quantity of mother bulbs established in the field, respectively (Table 1). In addition, two surveys were conducted to collect data on input used and production of big onion true seed relevant to Yala 2009 and Maha season 2008/2009.

A production function was estimated for big onion production constituting total production of big onion per farm as the dependent variable and farm size, seeds amount used, labour used, amount of fertilizer applied (nitrogen, phosphorous, and potassium), cost of chemical weed control and cost of plant protection measures(insect pest and disease control), and two dummy variables: one for type of true seed used (local vs. imported) and other for cultivation season (2007 Yala vs. 2009 Yala) as independent variables. The function was specified in $\log$ - $\log$ form so that the coefficients of the continuous variables show the production elasticities of respective inputs. The exponential value of the coefficient of the dummy variables shows the ratio of levels of production when the dummy variable takes the value of one $v s$. that of zero.

\section{Cost-benefit analysis}

Complete budgets were prepared for big-onion cultivation for Yala 2007 and 2009 and local true seed production for Yala 2007 and Maha 2008/09. The following indicators were used in assessing the financial performance: (i) Return to man day (ii) Return to capital (gross return/cost of cultivation excluding imputed cost) and (iii) Benefit/ Cost ratio $\sum_{j=1}^{n} B_{j} / \sum_{j=1}^{n} C_{j}$

where, $B_{j}=$ benefits $(R s /$ ha $)$ of $j^{\text {th }}$ farmer, $C_{j}=\operatorname{costs}(R s / h a)$ of $j^{\text {th }}$ farmer 
Table 1. Selection of the sample size

\begin{tabular}{lcccccc}
\hline & \multicolumn{2}{c}{ Yala 2007} & \multicolumn{2}{c}{ Yala 2009 } & Yala 2007 & $\begin{array}{c}\text { Maha } \\
\mathbf{2 0 0 8 / 0 9}\end{array}$ \\
\hline $\begin{array}{l}\text { Agrarian } \\
\text { Service } \\
\text { Centre }\end{array}$ & $\begin{array}{c}\text { Number of } \\
\text { farmers using } \\
\text { local true } \\
\text { seeds }\end{array}$ & $\begin{array}{c}\text { Number of } \\
\text { farmers } \\
\text { ing impor- } \\
\text { ted true } \\
\text { seeds }\end{array}$ & $\begin{array}{c}\text { Number of } \\
\text { ingers us- }\end{array}$ & $\begin{array}{c}\text { Number of } \\
\text { farmers us- } \\
\text { true seeds } \\
\text { ing impor- } \\
\text { ted true } \\
\text { seeds }\end{array}$ & $\begin{array}{c}\text { Number of } \\
\text { seed onion } \\
\text { farmers }\end{array}$ & $\begin{array}{c}\text { Number of } \\
\text { seed onion } \\
\text { farmers }\end{array}$ \\
\hline Dambulla & 2 & 18 & 12 & 17 & & \\
Kimbissa & 25 & 11 & 14 & 19 & 31 & 13 \\
Galewela & 8 & 7 & 8 & 3 & 2 & 10 \\
Total & 35 & 36 & 34 & 39 & 37 & 37 \\
\hline
\end{tabular}

\section{RESULTS AND DISCUSSIONS}

\section{Estimation of production function}

Results of the production function estimation are presented in Table 2. Coefficients of the model are statistically significant except for amount of fertilizer used, cost of chemical weed control and cost of plant protection. The model explains $79 \%$ of behaviour of the dependent variable with respect to selected independent variables. The slope coefficients of the production function are production elasticities. The slope coefficients of farm size, amount of seed used, total labour used, cost of power used indicated that $1 \%$ increase in each parameter contributed to $0.4 \%, 0.17 \%, 0.24 \%$ and $0.12 \%$ increase in big onion production, respectively. The coefficients of the dummy variables indicate that production using local seed was significantly larger than that of imported seed and the production in 2007 Yala season is significantly larger than that of 2009 Yala season. Furthermore, the results implied that yield of big onion produced from local true seeds was 1.32 times higher than that from imported true seed. Such yield advantages are equivalent to an additional yield of 2,320 and 2,825 $\mathrm{kg}$ per farm in Yala 2007 and 2009, respectively.

Table 2. The results of the estimation of production function

\begin{tabular}{|c|c|c|c|c|}
\hline Predictor variables & Mean & Coeff. & SE. coeff & p value \\
\hline Constant & & *6.405 & 0.582 & 0.000 \\
\hline LnX $X_{1}$-Farm size (ha) & 0.43 & ${ }^{* * *} 0.405$ & 0.091 & 0.000 \\
\hline $\mathrm{LnX}_{2}$-Amount of seed used $(\mathrm{kg} /$ farm $)$ & 3.2 & ${ }^{* *} 0.177$ & 0.086 & 0.040 \\
\hline $\operatorname{LnX}_{3}$-Total labour used (mandays) & 163.5 & ${ }^{* * * *} 0.245$ & 0.085 & 0.005 \\
\hline $\mathrm{LnX}_{4}$-Amount of Nitrogen used ( $\mathrm{kg} /$ farm) & 51.25 & 0.001 & 0.009 & 0.895 \\
\hline $\mathrm{LnX}_{5}$ - Amount of Phosphorous used (kg/farm) & 64.94 & 0.034 & 0.034 & 0.317 \\
\hline $\operatorname{LnX}_{6}$-Amount of Potassium used $(\mathrm{kg} /$ farm $)$ & 101.67 & -0.004 & 0.007 & 0.577 \\
\hline $\mathrm{LnX}_{7}$-Cost of chemical weed control (Rs/farm) & 4667.06 & 0.005 & 0.010 & 0.622 \\
\hline $\mathrm{LnX}_{8}$-Cost of plant protection (Rs/farm) & 11101.13 & -0.002 & 0.044 & 0.965 \\
\hline $\mathrm{LnX}_{9}$-Power cost (Rs/farm) & 15847.24 & ${ }^{* *} 0.123$ & 0.050 & 0.014 \\
\hline $\mathrm{X}_{10}$-Type of seeds used (dummy: loc & & ${ }^{* * *} 0.276$ & 0.054 & 0.000 \\
\hline $\mathrm{X}_{11}$-Cultivation season (dummy: $2007=1$ ) & & ${ }^{* * * *} 0.197$ & 0.059 & 0.001 \\
\hline No. of observations 142 & \multicolumn{4}{|c|}{$R^{2}(\operatorname{adj})=77.4 \%$} \\
\hline
\end{tabular}

Dependent variable $\mathrm{LnY}$-Yield ( $\mathrm{kg}$ per farm) mean yield $9153.47 \mathrm{~kg} /$ farm

$* *$ Significant at $\mathrm{p}=0.05, * * *$ Significant at $\mathrm{p}=0.01$ 


\section{Profitability of big onion production by type of true seeds}

Cost of production of big onion with local true seeds and imported true seeds is presented in Tables 1 and 2 for Yala seasons 2007 and 2009, respectively. It is clear that the cost of seeds constitutes approximately 10 and 5\% of total cost of production in case of local true seed usage vs. imported true seed usage, respectively. The cost of production of big onion was higher by $32.94 \%$ and $12.78 \%$ in Yala 2007 and 2009 when local true seeds were used compared to imported seeds.

Yield and returns of big onion production using local true seeds and imported true seeds in Yala season of 2007 and 2009 are presented in Table 3. The results show that local true seeds bring about $41 \%$ and $25 \%$ yield increase compared to that of imported true seed in Yala 2007 and 2009, respectively. These values are on the lower side when compared to findings of Lesly et al (2002), who reported that average yield performance of local true seed and imported true seed were $34,580 \mathrm{~kg} / \mathrm{ha}$ and $27,170 \mathrm{~kg} / \mathrm{ha}$, respectively.

Average farm-gate price of big onion produced using local true seed is higher than that using imported true seed (Table 3). The higher price was due to the fact that storability, uniformity, and higher consumer preference of bulbs which were harvested from local true seed. Even though the total cost of production was higher with local true seeds, the profitability indicators showed higher returns from big onion cultivation when local seeds are used due to higher yields performance of local true seed.

Table 3. Yield and returns of big onion production using local true seed and imported true seeds

\begin{tabular}{lrrrr}
\hline \multirow{2}{*}{ Yield and returns } & \multicolumn{2}{c}{ Yala 2007 } & \multicolumn{2}{c}{ Yala 2009 } \\
\cline { 2 - 5 } & $\begin{array}{c}\text { Local } \\
\text { true seeds }\end{array}$ & $\begin{array}{l}\text { Imported } \\
\text { true seeds }\end{array}$ & $\begin{array}{c}\text { Local } \\
\text { true seeds }\end{array}$ & $\begin{array}{r}\text { Imported } \\
\text { true seeds }\end{array}$ \\
\hline Average yield (kg/ha) & $25,580.48$ & $18,140.71$ & $22,341.39$ & $17,792.10$ \\
Farm gate price of produce (Rs/kg) & 40.43 & 32.47 & 50.00 & 37.48 \\
Gross income (Rs/ha) & $1,034,218.81$ & $589,028.85$ & $1,117,069.53$ & $666,925.32$ \\
Profit (Including imputed cost) & $686,649.40$ & $327,578.91$ & $618,670.49$ & $230,500.47$ \\
(Rs/ha) & & & & \\
Profit (Excluding imputed cost) & $755,074.14$ & $382,230.70$ & $787,747.35$ & $332,453.72$ \\
(Rs/ha) & & & & \\
Per unit cost (Including imputed cost) & 13.59 & 14.41 & 22.31 & 24.53 \\
(Rs/kg) & 10.91 & 11.40 & 14.74 & 18.80 \\
Per unit cost (Excluding imputed cost) & & & & \\
(Rs/kg) & 2.98 & 2.25 & 2.24 & 1.53 \\
Benefit/Cost & $1,960.62$ & $1,265.85$ & $1,894.90$ & $1,018.33$ \\
Return to labour (Rs/man day) & 3.70 & 2.85 & 3.39 & 1.99 \\
Return to capital & & &
\end{tabular}

\section{Profitability of producing local true seed}

Cost of production and returns of producing local true seed in Yala and Maha seasons are presented in Table 4. The benefit cost ratio, return to labour and return to capital were 2.01, 1448.63, 2.72, respectively for Yala season 2007 indicating that the local true seed production is financially feasible. The benefit cost ratios, return to labour and return to 
capital of true seed production were higher in Maha 2008/2009 due to higher farm gate price that prevailed in the season.

Generally, average receivable true seed yield was relatively low in Maha season compared to Yala seasons. Field experience showed that the climatic condition that prevailed in the yala season is preferred for producing true seed under open environmental condition without incurring high cost of production. However, true seed production in Maha season is a very costly and difficult task due to high cost of pest and disease management and maintaining rain protected environment for seed production plots. Although there have been higher benefit cost ratio, return to labour and return to capital of true seed production in maha season those figures are due to high farm gate price that prevailed in Maha season 2008/2009. In terms of true seed yield obtained and low cost of production, most suitable season for true seed production is the Yala season.

Table 4. Cost and returns of producing a unit of local true seeds

\begin{tabular}{lrr}
\hline Parameter & Yala 2007 & Maha 2008/09 \\
\hline Cost of producing a unit of local true seed & & \\
Cost of labour including imputed cost (Rs/kg) & $1,151.89$ & $1,794.76$ \\
Cost of labour excluding imputed cost (Rs/kg) & 303.92 & 187.77 \\
Cost of power (Rs/kg) & 100.09 & 160.84 \\
Cost of material (Rs/kg) & $2,004.80$ & $2,447.73$ \\
Total cost including imputed cost (Rs/kg) & $3,256.79$ & $4,403.33$ \\
Total cost excluding imputed cost (Rs/kg) & $2,408.81$ & $2,796.34$ \\
Yield and returns of producing $\boldsymbol{a}$ unit of local seed & & \\
Average yield (seed $\mathrm{kg} / \mathrm{kg}$ of mother bulbs) & 0.08 & 0.07 \\
Price of produce (Rs/ kg of seed) & $6,552.17$ & $8,901.16$ \\
Profit (Including imputed cost) (Rs/kg of seed) & $3,295.39$ & $4,497.82$ \\
Profit (Excluding imputed cost) (Rs/kg of seed) & $4,143.36$ & $6,104.82$ \\
Benefit/Cost ratio & 2.01 & 2.02 \\
Return to labour(Rs/man day) & $1,448.63$ & $2,860.27$ \\
Return to capital & 2.72 & 3.18 \\
\hline
\end{tabular}

${ }^{3}$ Presented in Rs $/ \mathrm{kg}$ as small extents are being used for true seed production

\section{CONCLUSIONS}

This study assessed the financial viability of big onion true seed production and commercial big onion production using locally produced true seeds in Matale district. Results of the production function estimation clearly show that the yields obtained using local true seeds is significantly higher than that of imported seeds. Even though the cost of production of big onion is higher with local true seeds, the farmers could sell the produce at a higher price due to greater storability and consumer preference on big onion produce it is more profitable to use local true seeds compared to that of imported true seeds. The results further indicate that local true seed production is a financially profitable venture in Matale district in terms of higher true seed yield obtained and low cost of production. It can also be concluded that the most suitable season for true seed production is the Yala season. 


\section{REFERENCES}

DCS (2009) Statistical Abstracts. Department of Census and Statistics, Colombo, Sri Lanka.

DOA (2004) Big Onion Cultivation (Sinhala), $2^{\text {nd }}$ edition, Department of Agriculture, Peradeniya, Sri Lanka. pp.38-44.

Edirimanna, E.R.S.P. (2003) Varietal Evaluation of big onion, Dharmasena P.B. Samarathunga H. and Nijamudeen M.S. (Eds.) Fifty years of research 1950-2000 (Review of past findings of Agricultural Research Mahailluppallama) Field Crop Research and Development Institute, Mahailluppallama, Department of Agriculture, Mahailluppallama, Sri Lanka.

Edirimanna, E.R.S.P and Rajapakse, R.G.A.S. (2003). Effect of cultural practices on seed yield of big onion (Allium cepa L.), Annals of the Sri Lanka Department of Agriculture vol.05, 2003 pp,69; Department of Agriculture, Peradeniya, Sri Lanka.

Lesly, W.D., Malaviarachchi M.A.P.W.K., Jayawardena, S.N. and Kumararathne M.J.M.P. (2002). Farmer management practices on the productivity of big onion in the dry zone of Sri Lanka, Annals of the Sri Lanka, Department of Agriculture Department of Agriculture, Peradeniya, Sri Lanka. vol. 04, pp. 385.

Mettananda K.A. (2006). Mother bulb storage of big onion (Allium cepa L.) for seed production during the Yala season, Annals of the Sri Lanka Department of Agriculture; Department of Agriculture, Peradeniya, Sri Lanka vol.08, pp.365. 